Salt of the Earth 



\title{
Salt of the Earth
}

The Political Origins of Peasant Protest and Communist Revolution in China

\author{
Ralph A. Thaxton, Jr.
}




\section{University of California Press \\ Berkeley and Los Angeles, California \\ University of California Press, Ltd. \\ London, England \\ (C) 1997 by the Regents of the University of California}

An earlier version of Chapter 2 of this book was published as "State Making and State Terror: The Formation of the Revenue Police and the Origins of Collective Protest in Rural North China during the Republican Period," Theory and Society 19(1990): 335-76.

Library of Congress Cataloging-in-Publication Data

Thaxton, Ralph, 1944-

Salt of the earth : the political origins of peasant protest and communist revolution in China / Ralph A. Thaxton, Jr.

p. $\mathrm{cm}$.

Includes bibliographical references and index.

ISBN 0-520-20318-6 (alk. paper)

1. Communism-China-History-2oth century. 2. Peasant uprisings-China-

History-2oth century. 3. China-Politics and government-2oth century. I. Title.

$\mathrm{HX}_{417}$ 17.5.T48 1997

$322.4^{\prime} 4^{\prime} 095^{109041-d c 20}$

$96-20359$

CIP

Manufactured in the United States of America

$\begin{array}{lllllllll}9 & 8 & 7 & 6 & 5 & 4 & 3 & 2 & 1\end{array}$

The paper used in this publication meets the minimum requirements of American National Standard for Information Sciences-Permanence of Paper for Printed Library Materials, ANSI Z $39 \cdot 4^{8-1984}$. 
To Janet, with affection and admiration 
